\title{
易感染者におけるメチシリン耐性黄色ブドウ球菌 \\ （MRSA）感染症の臨床的検討
}

\begin{tabular}{lllllll}
\multicolumn{8}{c}{ 久留米大学第 1 内科 } \\
川山 & 智隆 & 德永 & 尚登 & 横山 俊伸 & 本田 & 順一 \\
名取 & 英世 & 市川洋一郎 & 大泉耕太郎 & &
\end{tabular}

(平成 5 年 2 月 23 日受付)

(平成 5 年 3 月 18 日受理)
Key words: methicillin-resistant Staphylococcus aureus (MRSA), nosocomial infection, compromised host, minimum inhibitory cncentration (MIC)

\begin{abstract}
要旨
1991年 1 月から 12 月まで久留米大学第 1 内科病棟に入院した患者を対象としてメチシリン耐性黄色ブ ドウ球菌(MRSA)の検出状況について検討した. MRSAを検出した患者は47例で, compromised host が大部分であった。 そのらち MRSA 感染症と診断されたのは $57.4 \%$ 高率であり, 敗血症, 肺炎が多く それぞれの死亡率も $75.0 \%, 57.1 \%$ と高率であった.MRSA 感染症の治療は積極的に行ら必要があるが, 緑膿菌との混合感染が多いため抗生剂の選択に注意を要すると思われた。当科に括いては, MRSA 感染 症に対してIPM+MINO またはIPM+FOM が使用され良好な成績を収めていた。これは 2 郕間の相 乗効果によると考兄られた. IPM と他薬剤との相乗効果の報告は in vitroにおいてはなされているが, 臨床報告例はあまりなされておらず，今後の MRSA 感染症治療上参考になりらると思われた。

MRSA の感受性検查成績から ABK, VCM, MINO の抗菌力が優れており, 特に VCM は臨床の場に おいてもその有効性が期待される.
\end{abstract}

\section{序文}

メチシリン耐性黄色ブドウ球菌 (以下 MRSA) は, 1961年に英国で初めて報告された ${ }^{1)}$. 当時はメ チシリン感性黄色ブドウ球菌 (以下 MSSA) に比 べ病原性が弱いため, 臨床上さほど問題とはなら なかった。

1980年代になり，第 3 世代セフェム系抗菌剤の 多用, 易感染者の増加に伴いMRSA は院内感染 症起炎菌として問題となってきた。現在では呼吸 器感染症, 敗血症の起炎菌として患者の予後を左 右することも少なくない，最近，ABK， VCMの 臨床使用が許可され, MRSA 感染症についての有

別刷請求先：（兵830）福岡県久留米市旭町67番地 久留米大学第 1 内科医局 川山 智隆
効性の検討が行われている.MRSA に関する基礎 的研究は数多くなされているが, 臨床研究報告は 少ない。

今回我々は, 久留米大学第 1 内科に打ける易感 染患者より分離させれた MRSA 株について基礎 的研究を行うとともにMRSA 感染症の発症につ ながる患者背景因子を調査・解析し, MRSA 感染 症対策を検討したので若干の文献的考察を加え 報告する。

\section{材料と方法}

\section{I) 対象}

検討対象とした症例は1991年 1 月から12月に 久留米大学病院第 1 内科病棟 (呼吸器内科, 血液 内科, 神経内科) に入院した患者のうち MRSA が 
検出された患者47症例である.

細菌学的検討には上述の患者からの単一または 複数の部位から分離同定された69株を使用した。

II) 方法

個々の症例の検討は診療録に記載された病歴, 臨床経過, 検査所見などをもとに行った。分離さ れた MRSA の起炎性の有無は自覚症状, X 線写 真扣よび白血球数, ESR 值, CRP 值などの炎症所 見より判断した.MRSA が持続的に分離されるが 炎症所見に乏しい患者を保菌者（carrier）とした。 臨床分離株の最小発育阻止濃度 (以下 MIC) 測 定は化学療法学会標準法に従い, 寒天平板希釈法 を用い測定した。抗菌別の薬剤濃度は $0.1,0.2$, $0.4,0.8,1.6,3.2,6.25,12.5,25,50,100 \mu \mathrm{g} /$ $\mathrm{ml}$ の11段階とし, 最終接種菌量を $10^{6} \mathrm{cfu} / \mathrm{ml}$ に調 整し, 寒天接種後 $37^{\circ} \mathrm{C} て ゙ 18$ 時間培養し MICを測 定した. MICの測定を行った薬剤は methicillin (DMPPC), piperacillin (PIPC), cefmetazol (CMZ), ceftizoxime (CZX), minocycline (MINO), imipenem(IPM), $\operatorname{arbekacin}(\mathrm{ABK})$, ofloxacin (OFLX), vancomycin (VCM) の 9 種
類である。

尚, DMPPCの MIC が $12.5 \mu \mathrm{g} / \mathrm{ml}$ 以上の株を MRSA とした。

\section{成 績}

I ) 患者背景 (Table 1)

患者の平均年齢は 59.7 歳であり，年歯令の幅は 20 歳から87歳であった。65歳以上の高齢者が全体の

Table 1 Profiles of 47 patients from whom strains of MRSA were isolated

(\%)

Age : Range : $20-87$ years old, Average ; 59.7 years old $38.3 \%$ of the patients were at the age of 65 year old and above

Sex : male vs female; $30(63.8)$ vs $17(36.2)$

$\begin{array}{lr}\text { Clinical situations* } & \\ \text { bed ridden } & 30(63.8) \\ \text { under control of artifical respiration } & 9(19.1) \\ \text { IVH cather indwelling } & 41(87.2) \\ \text { having malignancy } & 31(66.0) \\ \text { concurrent infection with P. aeruginosa } & 29(61.7)\end{array}$

*In a majority of the patients, the above situations were overlapped

Table 2 Diagnoses of 47 patients from whom MRSA were isolated

\begin{tabular}{|c|c|c|}
\hline & Diagnosis & $\begin{array}{c}\text { No. of } \\
\text { patients }(\%)\end{array}$ \\
\hline \multirow[t]{7}{*}{ Hematological diseases } & leukemia & 14 \\
\hline & malignant lymphoma & 7 \\
\hline & malignant hystiocytosis & 2 \\
\hline & myelodysplastic syndrome & 2 \\
\hline & multiple myeloma & 1 \\
\hline & aplastic anemia & 2 \\
\hline & myelofibrosis & 1 \\
\hline Subtotal & & $29(61.7)$ \\
\hline \multirow[t]{5}{*}{ Respiratory diseases } & lung cancer & 4 \\
\hline & pleural mesothelioma & 1 \\
\hline & pneumonia & 3 \\
\hline & pulmonary edema & 3 \\
\hline & chronic obstructive pulmonary disease & 1 \\
\hline Subtotal & & $12(15.5)$ \\
\hline \multirow[t]{5}{*}{ Neurological diseases } & cerebral infarction & 2 \\
\hline & anoxic encephalopathy & 1 \\
\hline & amyotrophic lateral sclerosis & 1 \\
\hline & viral encephalitis & 1 \\
\hline & Guillain-Barre syndrome & 1 \\
\hline Subtotal & & $6(12.8)$ \\
\hline Total & & $47(100)$ \\
\hline
\end{tabular}


約 $88.3 \%$ 占めていた。寝たきり状態例, 経口栄 養摂取不能による中心静脈栄養 (IVH) カテーテ ル留置例抒よび基礎に悪性疾患を有する例はかな りの例で重複して扮りいずれも過半数を占めてい た。

\section{II）基礎疾患（Table 2)}

当科での MRSA 検出患者の基礎疾患は血液疾 患が 29 例と最も多く, 次いで呼吸器疾患 12 例, 神 経疾患 6 例であった。いずれの疾患群でも悪性疾 患，免疫不全患者が多数を占めていた。神経疾患 例はいずれもべッド上で介助が必要な患者で，い わゆる寝たきりの状態であった。

III）臨床経過

MRSA 感染症が確実であると判断できるかあ るいは強く疑われる患者は MRSA が分離された 47例中27例であった。すなわち当科入院患者では
Table 3 Clinical status of 47 patients from whom strains of MRSA were isolated

\begin{tabular}{lc}
\hline & $\begin{array}{c}\text { No. of } \\
\text { patients(\%) }\end{array}$ \\
\hline $\begin{array}{l}\text { Definite or strongly suggestive } \\
\text { of MRSA-infection } \\
\text { Site of infection } \\
\quad \text { Sepsis }\end{array}$ & $23(48.9)$ \\
$\quad$ Sepsis and pneumonia & $11(23.4)$ \\
$\quad$ Pneumonia & $1(2.1)$ \\
$\quad$ Urinary tract infection & $6(12.8)$ \\
$\quad$ Postoperative wound infection & $3(6.4)$ \\
$\quad$ Periproctal abscess & $1(2.1)$ \\
Equivocal infection despite & $2(2.1)$ \\
continual isolation of MRSA & $4(8.5)$ \\
Single or only sporadic isolation & \\
$\quad$ MRSA but no apparent infection & $20(42.6)$ \\
& $47(100)$ \\
\hline
\end{tabular}

Table 4 Clinical courses of patients with MRSA sepsis

\begin{tabular}{|c|c|c|c|c|c|c|c|c|}
\hline \multirow[b]{2}{*}{ Case } & \multirow[b]{2}{*}{ Age } & \multirow[b]{2}{*}{ Sex } & \multirow[b]{2}{*}{ Diagnosis } & \multirow{2}{*}{$\begin{array}{l}\text { Concurrent } \\
\text { infection with } \\
\text { P. aeruginosa }\end{array}$} & \multirow[b]{2}{*}{ Clinical course } & \multirow{2}{*}{\multicolumn{2}{|c|}{$\begin{array}{l}\text { Antibiotics used } \\
\text { immediately before and } \\
\text { after the onset of sepsis }\end{array}$}} & \multirow[b]{2}{*}{ Outcome } \\
\hline & & & & & & & & \\
\hline 1 & 59 & $\mathrm{~F}$ & ML & yes & Post op. $\rightarrow$ sepsis $\rightarrow$ DIC & $(-)$ & $\left(\begin{array}{l}\mathrm{CAZ} \\
\mathrm{ABK}\end{array}\right.$ & died* \\
\hline 2 & 69 & $\mathrm{~F}$ & AML & no & Colitis $\rightarrow$ sepsis $\rightarrow$ shock & $\left(\begin{array}{l}\text { CMNX } \\
\text { DKB }\end{array}\right.$ & $\left(\begin{array}{l}\text { AMK } \\
\text { DKB } \\
\text { MINO }\end{array}\right.$ & died $^{*}$ \\
\hline 3 & 68 & $\mathrm{M}$ & AML & no & Sepsis $\rightarrow$ shock & $(-)$ & $(-)$ & died* \\
\hline 4 & 50 & $\mathrm{~F}$ & pulmonary edema & no & Sepsis $\mathrm{sp} \rightarrow$ shock & $(-)$ & FMOX & died* \\
\hline 5 & 69 & M & ATL & no & Sepsis $\rightarrow$ DIC & $(-)$ & $\left(\begin{array}{l}\text { IPM } \\
\text { MINO } \\
\text { FOM }\end{array}\right.$ & died $^{*}$ \\
\hline 6 & 48 & M & ATL & no & Sepsis + pneumonia $\rightarrow$ carrier & $\left(\begin{array}{l}\text { PIPC } \\
\text { MINO }\end{array}\right.$ & $\left(\begin{array}{l}\text { ISP } \\
\text { CAZ } \\
\text { VCM }\end{array}\right.$ & $\operatorname{died}^{* *}$ \\
\hline 7 & 46 & M & ML & yes & Sepsis $\rightarrow$ carrier & $\left(\begin{array}{l}\text { IPM } \\
\text { ABK } \\
\text { MINO }\end{array}\right.$ & $\left(\begin{array}{l}\text { IPM } \\
\text { ABK } \\
\text { VDM }\end{array}\right.$ & $\operatorname{died}^{* *}$ \\
\hline 8 & 63 & $\mathrm{~F}$ & CML & yes & $\begin{array}{l}\text { Sepsis } \rightarrow \\
\text { negative blood culture }\end{array}$ & $\left(\begin{array}{l}\mathrm{CZX} \\
\mathrm{DKB}\end{array}\right.$ & $\left(\begin{array}{l}\text { IPM } \\
\text { FOM }\end{array}\right.$ & $\operatorname{died}^{* *}$ \\
\hline 9 & 48 & M & Lung cancer & yes & $\underset{\text { negsis } \rightarrow}{\text { negative blood culutre }}$ & $\left(\begin{array}{l}\mathrm{CZX} \\
\mathrm{DKB}\end{array}\right.$ & $\left(\begin{array}{l}\text { IPM } \\
\text { FOM }\end{array}\right.$ & $\operatorname{died}^{* *}$ \\
\hline 10 & 62 & $\mathrm{M}$ & $\begin{array}{l}\text { Guillain-Barre } \\
\text { syndrome }\end{array}$ & yes & Sepsis $\rightarrow$ carrier & $\left(\begin{array}{l}\text { CAZ } \\
\text { AMK }\end{array}\right.$ & $\left(\begin{array}{l}\text { IPM } \\
\text { MINO } \\
\text { FOM }\end{array}\right.$ & alive \\
\hline 11 & 69 & $\mathrm{M}$ & ML & yes & Sepsis $\rightarrow$ carrier & $\left(\begin{array}{l}\text { CZX } \\
\text { AMK }\end{array}\right.$ & $\left(\begin{array}{l}\text { IPM } \\
\text { MINO }\end{array}\right.$ & alive \\
\hline 12 & 48 & $\mathrm{M}$ & ML & yes & $\begin{array}{l}\text { Sepsis sp } \rightarrow \\
\text { negative blood culutre }\end{array}$ & $\left(\begin{array}{l}\mathrm{CMNX} \\
\mathrm{DKB}\end{array}\right.$ & $\left(\begin{array}{l}\text { IPM } \\
\text { FOM }\end{array}\right.$ & alive \\
\hline
\end{tabular}

*died from MRSA sepsis ${ }^{* *}$ died from the original disease

Abbreviations AML: acute myelocytic leukemia/ML: malignant lymphoma/ATL : adult T cell leukemia/CML : chronic myelocytic leukemia/DIC : disseminated intravascular coagulation syndrome

CAZ : ceftazidime/ABK : albekacin/CMNX : cefminox/DKB : dibekacin/AMK : amikacin/MINO : mynocycline/FMOX : flomoxef PIPC : piperacillin ISP : isepamicin/VCM : vancomycin/IPM : imipenem/CZX : ceftizoxime/FOM : fostomycin 
Table 5 Clinical Course of Patients with MRSA pneumonia

\begin{tabular}{|c|c|c|c|c|c|c|c|}
\hline Case & Age & Sex & Diagnosis & $\begin{array}{c}\text { Artificial } \\
\text { respiration }\end{array}$ & Clinical course & Therapy & Outcome \\
\hline 1 & 48 & $\mathrm{M}$ & ALL & no & $\begin{array}{l}\text { pneumonia } \rightarrow \text { sepsis } \rightarrow \\
\text { shoke }\end{array}$ & $\begin{array}{l}\text { VCM } \\
\text { ISP } \\
\text { CAZ }\end{array}$ & died \\
\hline 2 & 57 & M & ADS & no & pneumonia $\rightarrow$ sepsis $\rightarrow$ DIC & $\left(\begin{array}{l}\text { IPM } \\
\text { MINO }\end{array}\right.$ & died \\
\hline 3 & 60 & M & $\mathrm{MH}$ & yes & pneumonia $\mathrm{sp} \rightarrow$ improved & $\left(\begin{array}{l}\text { IPM } \\
\text { ABK }\end{array}\right.$ & died from $\mathrm{MH}$ \\
\hline 4 & 76 & M & mesothelioma & yes & pneumonia $\mathrm{sp} \rightarrow$ improved & $\left(\begin{array}{l}\text { IPM } \\
\text { AMK }\end{array}\right.$ & $\begin{array}{l}\text { died from } \\
\text { mesothelioma }\end{array}$ \\
\hline 5 & 60 & $\mathrm{M}$ & $\mathrm{MH}$ & no & pneumonia sp $\rightarrow$ & (IPM & improved $\rightarrow$ alive \\
\hline 6 & 70 & $\mathrm{M}$ & Lung cancer & no & pneumonia $\rightarrow$ carrier & (AMK & alive \\
\hline 7 & 35 & $\mathrm{M}$ & Lung cancer & no & pneumonia $\rightarrow$ carrier & $\left(\begin{array}{l}\text { IPM } \\
\text { FOM }\end{array}\right.$ & alive \\
\hline
\end{tabular}

Abbreviations : $\mathrm{MH}=$ malignant histiocytosis.

Abbreviation of the names of amtibiotics were the same as those described in the foot notes of Table 4 .

MRSA 分離例に占める MRSA 感染症発症率は 57.4\%であった（Table 3).

感染部位の内訳は，敗血症11例，肺炎 7 例，尿 路感染症 3 例, 術後創部膿瘍 1 例, 肛門周囲膿瘍 1 例であり, 敗血症および肺炎等の重複感染症例 もあった。

単なるMRSAの分離に止まり感染症の発症を みなかった患者のうち保菌者は 4 例であった。

MRSA による敗血症の診断が確定した 12 名の 症例につき患者背景, 治療及び予後を検討した (Table 4). 敗血症患者の12例中10例 (83.3\%) は 悪性疾患であった。12例全例にIVH 管理がなさ れていた。また表には示していないが MRSA 検 出前より緑膿菌が持続的に検出された患者は12例 中 7 例 (58.3\%) であった。緑膿菌に対して抗生 剂を使用していた例は 7 例中 6 例であった。

MRSA 敗血症が直接死因と考兄られた例は 5 例 (41.7\%) であった（Table 4). らち2 例は播 種性血管内凝固症候群 (以下 DIC) を併発した。 また，4例では緑膿菌の合併が認められず, MRSA 検出群に前もって抗生剂が投与されてい た例は 1 例のみであった。

治療により MRSA 敗血症が改善した例は残り の 7 例で, 万ち 4 例は原疾患の増悪のため死亡し, 生存例はわずか 3 例であった. MRSA が完全に消 失した者は生存 3 例のなかの 1 例（case 12）にす
ぎなかった。

MRSA 敗血症の治療としてはIPM の使用が 多く, 併用薬荗としてはFOM または MINO が多 かった。 IPM+MINO または IPM+FOM での改 善率は66.7\%であった。しかし MRSA 敗血症を 括こした例の死亡率は 12 例中 9 例 $(75.0 \%)$ と非 常に高率であった。

次にMRSA による呼吸器感染症についても敗 血症と同様な検討を行った(Table 5). MRSA 肺 炎に注目してみると, MRSA 肺炎を発症した 7 例 のらちこれが直接死因になった例は 2 例であっ た。をたこの 2 例は同時に敗血症を併発していた。 これら 2 症例にVCM の投与を試みたが満足すべ き結果は得られなかった。

MRSA 肺炎の死亡率は 7 例中 4 例 (57.1\%) で あった。

IV）MRSAの薬剤感受性分布

Table 6 に示した検体より分離同定された MRSA 69株の薬剂感受性を測定した。

薬剤感受性分布はMIC の累積百分率で表わし た(Fig. 1)，VCM，ABK，MINO に対する感受 性の高いことが知られた。 VCM は全菌株に対し $\mathrm{MIC}$ が $3.2 \mu \mathrm{g} / \mathrm{ml}$ ないしそれ以下の抗菌力を示 した. $\mathrm{ABK}$ の $\mathrm{MIC} か ゙ 3.2 \mu \mathrm{g} / \mathrm{ml}$ ないしそれ以下 の株は69株中54株（78.3\%）であった。

当科に招いては MRSA 感染症に対し, IPM が 
Fig. 1 Distribution and cumulative curves of MICs of nine agents against a total of 69 clinical isolates of MRSA

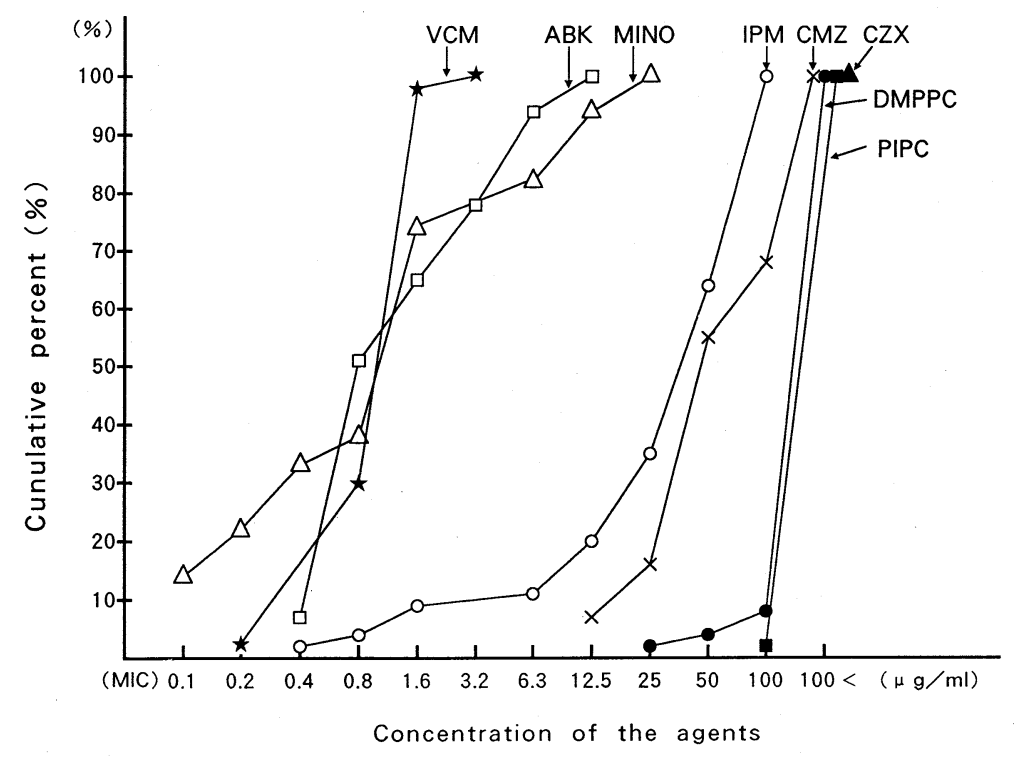

Table 6 Specimens from which MRSA wewe isolated

\begin{tabular}{lr}
\hline Pharyngeal swab & 21 \\
Sputum & 11 \\
BALF*) & 1 \\
Nasal cavity bruhing & 3 \\
Urine & 12 \\
Faeces & 8 \\
Blood & 6 \\
Pus & 4 \\
Others & 3 \\
Total & 69 \\
\hline
\end{tabular}

${ }^{*}$ BALF : Bronchoalveolar lavage fluid

多く使用されていたが, IPM の MIC が $3.2 \mu \mathrm{g} / \mathrm{ml}$ ないしそれ以下の株はわずか 7 株と少なかった。

\section{考 察}

当科に扔いて MRSA が検出された患者のなか で, 高齢者の占める割合は $38.6 \%$ とそれほど高く はなかったものの, 従来指摘 ${ }^{2)}$ (4)されいるよう に，悪性疾患患者や免疫不全状態にあるいわゆる compromised host が圧倒的多数を占めていた。

これらの患者のうち約半数は MRSA 感染症を発 症しており，特にMRSA敗血症を発症した患者 の死亡率は強力な化学療法の施行にもかかわら
ず，75\%と高率であった。一般に MSSA を含む黄 色ブドウ球菌敗血症の死亡率は 20 ～40\%とされて いるが5)，我々の結果はそれを遙かに上回ってい た. MRSA MSSA と比べ病原性も弱く,むし ろ弱毒菌に近いとされている。しかし MRSA は compromised host に対し容易にしかも高率に感 染症を起こし，患者の予後を左右する重要な因子 の一つであることが明らかとなっている。そのた めMRSA 感染症に対しては積極的治療が必要と 考えられる。

一方, 臨床の場に拉いて MRSA が検出されて も，それが感染症を抗こしているか否かを判断す ることは必ずしも容易ではない. MRSA が検出さ れる患者では MRSA 以外にも他の病原微生物に よる感染症がすでに成立していることも少なくな い.MRSA 感染症成立の有無は, 菌量の変化, 自 覚症状, X 線写真所見, 白血球数, CRP 值揖よび ESR 值などより総合的に判断する必要がある。緑 膿菌との混合感染例では特に注意を要する。我々 の施設においても緑膿菌が同時に検出された例は 29例 (61.7\%)であった。したがって MRSA 感染 症の治療に際しては，混合感染起炎菌も考慮に入 れた多剂併用療法が望ましいと思われる。当科に 
扣いては緑膿菌が先に検出されているためか, MRSA に対する抗菌力がそれほど強力とは言え ないIPM の使用が多かった。併用薬剂としては FOM, MINO が大部分であった。自験例では $\mathrm{IPM}+\mathrm{MINO}$ や IPM +FOM の併用で MRSA が減少をたは消失した例は $66.7 \%$ あり，これら の併用療法がある程度の有効性を示したと考えら れ，2 剂間の相乗効果に基づくものと考学れれた。 MRSA に対する 2 薬剤間の in vitro 相乗効果に 関する報告はなされているが6)，我々が調べたか ぎりでは，上記併用療法の有用性に言及した臨床 報告例は少ない.今後 MRSA 感染症, 特に MRSA 敗血症, の治療上参考となりらると思われ た。

最近, ABK が MRSA 感染症に対して臨床的使 用が可能となり，その有効性を指摘した報告も多 (7). 当科に括いても5 例の患者に $\mathrm{ABK}$ が使用さ れて扣り, 多剤との併用例も含まれるものの菌消 失もしくは減少例は $3 / 5$ 例 $(60.0 \%)$ と比較的高率 であった. ABKはアミノグリコシド系抗生物質 を賦活化させる $2^{\prime}$-リン酸転移酵素, $4^{\prime}$-アデニリル 転移酵素, $3^{\prime}$-リン酸転移酵素に対して安定であり 耐性菌が産生されにくいとされている。しかし当 科の臨床分離株に沶いて既に MIC が $3.2 \mu \mathrm{g} / \mathrm{ml}$ 以上の ABK 耐性株が15株 (21.7\%) 出現してきて いる.

さらに，我が国でもMRSAの治療薬として注 目されているVCM の静脈内投与が許可された。 当科での臨床分離株 69 株は全て VCM に対して優 れた感受性を示していた。 VCM 静注例はまだ 2 例と少なく有効性について結論すべき段階にな

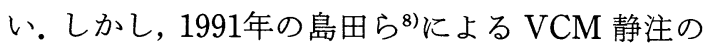
治験成績によれば，有効率は $89.2 \%$ と高く，乙か も，先行他抗菌剂が無効であった症例に対しても 有効率 $91.1 \%$ と優れた結果を得ている. 欧米では
MRSA 感染症にたいして第一選択薬とする施設 も多く，有効であるとの報告も多い9．また，いま だ VCM 耐性黄色ブドウ球菌は出現していない。 今後, MRSA 感染症に対するVCM の臨床的有用 性が実証されるものと期待される。

\section{文献}

1) Jevons, M.P.: “Celbenin"-resistant Staphylococci. Brit. Med. J., 1 : 124-125, 1961.

2) 重野芳輝, 山城哲, 草野展周: MRSA 感染症 一呼吸器感染症における MRSA一, 臨床病理, 9: 1005-1015, 1990.

3) 陳 端明, 菊池典雄, 河野典博, 中村 明, 渡辺 正治, 菅野重治, 栗山喬之：喀痰からの MRSA 分 離状況とその呼吸器感染症について一千葉大学付 属病院における最近 5 年間の検討. 日胸疾会誌, $25: 1330-1340,1987$.

4）永武 毅, 松本慶蔵, 宾戸春美, 宇塚良夫, 山本 真志, 田口幹夫, 力富直人, 吉田俊昭, 隆杉正和, 高橋 淳, 大石和徳, 坂本 翊, 屋富祖夏樹, 鈴 木 寛, ムバキ.ソシアラ, 渡辺貴和雄 : 老人病院 における細菌肺炎と裖創感染の起炎菌に関する検 討（第 1 報）一院内感染としてのMRSA一. Chemotherapy, 34:240-249, 1986.

5) Mylotte, J.M., McDermott, C. \& Spooner, J.A. : Prospective study of 114 consecutive episodes of Staphylococcus aureus bacteremia. Rev. Infect. Dis., 9: 891-907, 1987.

6）西園寺克, 設楽政次, 小林寅吉：Fosfomycin 耐性 MRSA に対するImipenim と Fostomycin の併 用効果の検討. Killing-curve methodによる成 績. Jpn. J. Anitibiot., 43: 379-387, 1990.

7）坂本 翊, 木下和久, 松本慶蔵, 永武 毅：最近 の多剂耐性黄色ブドウ球菌感染症に対する HBK の臨床的研究. 化学療法の領域, 4:1381-1388, 1988.

8）島田 馨, 花谷勇治, 目黒英典, 菅野治重：MRSA による重症感染に対する注射用塩酸バンコマイシ ンの臨床研究. Chemotherapy, $40: 86-101,1992$.

9) Kucer, A. \& Bennt, N.M.: The Use of Antibiotics, 4th ed., p. 1045-1068, William Heinemann Medical Books, London, 1987. 
In Vitro and Clinical Studies of MRSA Infections in Compromised Hosts

Tomotaka KAWAYAMA, Naoto TOKUNAGA, Toshinobu YOKOYAMA, Junichi HONDA, Hideo NATORI, Yoichiro ICHIKAWA \& Kotaro OIZUMI

First Department of Internal Medicine, Kurume University, Kurume, Japan

From January to December 1991, 47 clinical cases in when methicillin-resistant Staphylococcus aureus (MRSA) strains were isolate were investigated at our internal medicine ward.

The MRSA infection rate was $57.4 \%$ (27/47). The mortality due to MRSA bacteremia was $75.0 \%$ (9/12) and that due to MRSA pneumonia was $57.1 \%$ (4/7). We think that MRSA infections must be treated by multiple antibiotics.

At out institution, most of the patients were given a combination therapy of imipenem + fosfomycin or imipenemt + mynocycline. Although in vitro the MICs of imipenem did not show excellent activity against MRSA strains, in vivo these combination therapy including imipenem showed excellent activity aganst MRSA infections. We think that this result was due to the additive effect of the two drug combination.

We determined the MICs of single antibiotics against MRSA strains. Most of the MRSA strains were sensitive to minocycline and arbekacin. All MRSA strains were sensitive to vancomycin we think that vancomycin is a highly useful drug to combat MRSA infection. 